\title{
DIET OF CRENICICHLA BRITSKII (PERCIFORMES: CICHLIDAE) IN A STREAM OF RIO AGUAPEÍ BASIN, UPPER RIO PARANÁ SYSTEM, SOUTHEASTERN BRAZIL
}

\author{
Fernando Zaniolo Gibran ${ }^{1}$ \\ Katiane Mara Ferreira ${ }^{1}$ \\ Ricardo M. C. Castro \\ Biota Neotropica v1 http://www.biotaneotropica.org.br/v1n12/pt/abstract?short- \\ communication+BN01001122001
}

Received:August, 27, 2001

Revised: December, 12, 2001

Accepted: December 30, 2001

\begin{abstract}
${ }^{1}$ Laboratório de Ictiologia de Ribeirão Preto (LIRP), Departamento de Biologia, FFCLRP-Universidade de São Paulo (www.ffclrp.usp.br), Av. Bandeirantes 3900, CEP 14040-901, Ribeirão Preto, São Paulo, Brazil

Correspondence to: F.Z. Gibran. e-mail: fergibran@hotmail.com

K.M. Ferreira: katianeferreira@hotmail.com

R.M.C. Castro: rmcastro@ ffclrp.usp.br
\end{abstract}

\begin{abstract}
Diet of Crenicichla britskii (Perciformes: Cichlidae) in a stream of Rio Aguapeí basin, Upper Rio Paraná system, southeastern Brazil

We qualitatively studied the gut contents of 20 specimens (36.1-71.3 mm standard length) of the pike cichlid Crenicichla britskii from a $100 \mathrm{~m}$ stretched second order stream running inside a small gallery forest in a large pasture area of Rio Aguapeí basin, State of São Paulo, southeastern Brazil. The diet, in terms of per cent composition, constituted primarily of aquatic insects $(50 \%)$ (mostly immature forms), crustaceans $(14.3 \%)$, unidentified organic material and filamentous green algae (both with 10.7\%), followed by fishes and arachnids (both with 7.1\%). Diet analysis indicates that C. britskii is a generalist insectivore with a relatively short digestive tube, which feeds on autochthonous items captured in a broad array of habitats such as in the water column or at the surface, buried in or over the bottom, or associated with macrophytes and submerged vegetation debris.
\end{abstract}

Key Words: Cichlidae, Crenicichla britskii, diet, Upper Rio Paraná system, southeastern Brazil.

\section{Resumo}

Dieta de Crenicichla britskii (Perciformes: Cichlidae) em um riacho da bacia do rio Aguapeí, Alto rio Paraná, sudeste do Brasil

Estudamos qualitativamente os conteúdos estomacais de 20 exemplares (36,1-71,3 mm de comprimento padrão) de Crenicichla britskii ("Jacundá" ou "Joaninha"), coletados na bacia do rio Aguapeí, Estado de São Paulo, sudeste do Brasil, em um trecho de $100 \mathrm{~m}$ de riacho de segunda ordem correndo no interior de uma mata de galeria rala localizada dentro de uma grande área de pastagem. A dieta, em termos de composição percentual, foi predominantemente constituída por insetos aquáticos $(50 \%)$ (principalmente estágios imaturos), crustáceos (14,3\%), material orgânico não identificado e algas clorofíceas filamentosas (ambos com 10,7\%), seguidos por peixes e aracnídeos (ambos com 7,1\%). A análise da dieta mostra que $C$. britskii é um insetívoro generalista que apresenta um tubo digestivo relativamente curto, e uma dieta composta por itens autóctones que captura na coluna d'água ou na superfície, enterrados ou sobre o substrato, ou ainda associados às macrófitas e restos vegetais submersos.

Palavras-chave: Cichlidae, Crenicichla britskii, dieta, bacia do Alto rio Paraná, sudeste do Brasil. 


\section{Introduction}

Crenicichla (pike cichlids), the most speciose genus of South American Cichlidae, contains 72 predatory species with elongated bodies, and occurs over most of tropical and subtropical cis-Andean South America (Ploeg 1991, Lucena \& Kullander 1992). Crenicichla britskii Kullander, 1982 (Fig. 1), is endemic of the Upper Rio Paraná basin, and although not rare, is not usually represented by large samples in scientific collections (pers. obs., see also Ploeg 1991). Our sampling efforts in the streams and headwaters of Upper Rio Paraná system yielded 34 individuals of this poorly known cichlid, with a good size range, in a single sampled stretch of stream. We present the diet of $C$. Britskii, along with a detailed description of the environment at the collection site and inferences of its feeding places, based on published information on the biology and habits of its prey.

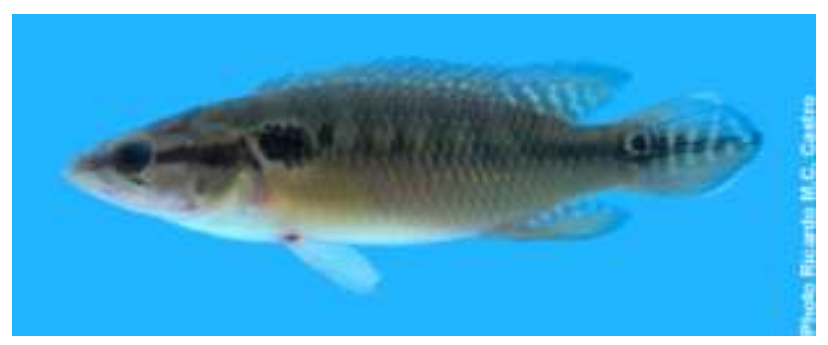

Fig. 1: A specimen of Crenicichla britskii (LIRP 1125 - 68.3 mm SL).

The so-called Upper Rio Paraná basin encompasses a huge number of streams and headwaters inhabited primarily by fish species of small overall size (mostly less than $120 \mathrm{~mm}$ in standard length, SL), with restricted geographical distributions and small or nonexistent commercial value. These species are highly dependent of the riparian vegetation for food, shelter and reproduction, and are thus highly susceptible to deleterious humans activities, including deforestation and the extensive use of fertilizers and pesticides associated with intensive agricultural activities (Castro \& Menezes 1998, Castro 1999).

\section{Material and Methods \\ 2.1 Study site}

Field work was carried out in a $100 \mathrm{~m}$ long stretch of Córrego Ariranha $\left(21^{\circ} 24^{\prime} 47.2^{\prime \prime} \mathrm{S}, 51^{\circ} 25^{\prime} 22.9^{\prime \prime} \mathrm{W}\right)$, a second order stream tributary to the Rio Aguapeí at approximately $300 \mathrm{~m}$ elevation in the Upper Rio Paraná system, at município de Junqueirópolis, São Paulo State, southeastern Brazil. The studied stretch of stream is located on a private cattle raising farm and runs through a large pasture area formerly covered by the semideciduous subtropical mesophytic forest of southern and southeastern Brazil (Hueck \& Seibert 1981). It is sheltered by a narrow, thin gallery of riparian vegetation (Fig. 2).

Geologically, the study site belongs to Bauru Basin, a huge depression formed in the Late Cretaceous filled with sandy sedimentary material, characterized by the presence of fine to very fine sandstones (Petri \& Fúlfaro 1988, Fernandes \&

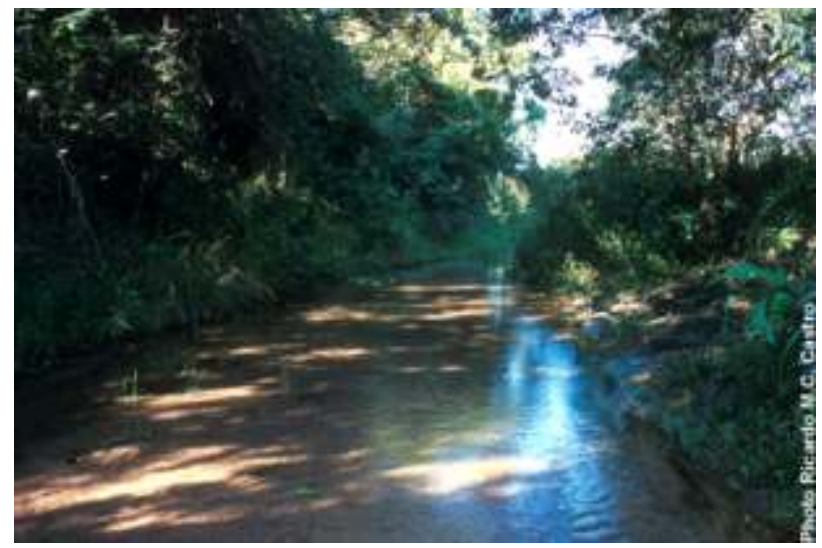

Fig. 2: A view of the study site. Córrego Ariranha, Upper Rio Paraná basin, Brazil.

Coimbra 1996). Climate is humid, warm tropical, with the rainy season (maximum rainfall in January) occurring during the summer (December to March) and the dry season (minimum rainfall in July) occurring during the winter (June to September). The mean annual temperature is $22^{\circ} \mathrm{C}$, and the mean annual rainfall is $1250 \mathrm{~mm}$ (Nimer 1989).

The stream stretch width ranged between 2.7 and $4.7 \mathrm{~m}$, average depth was $0.1 \mathrm{~m}$ (maximum of $0.3 \mathrm{~m}$ ), and bottom was largely covered by medium to fine sand, and was almost completely devoid of submerged fallen litter, with submerged (Bacopa sp. and Ceratophyllum dermersum), and semi-submerged (Oryza sp., Heteranthera cf. reniformes and Scleria sp.) macrophytes. Air and water temperature were 25 and $23^{\circ} \mathrm{C}$ respectively, horizontal water transparency $0.7 \mathrm{~m}$, average current velocity 0.34 $\mathrm{m} . \mathrm{s}^{-1}$, dissolved oxygen $9.3 \mathrm{mg} . \mathrm{L}^{-1}, \mathrm{pH} 7.1$, and conductivity 125 S.cm ${ }^{-1}$.

Together with the $C$. britskii, we also collected Hoplias malabaricus, Pyrrhulina australis, Astyanax altiparanae, Bryconamericus sp., Moenkhausia sanctaefilomenae, Piabina argentea, Serrapinus notomelas, Acestrorhynchus lacustris, Imparfinis mirini, Pimelodella sp., Corydoras aeneus, Hypostomus ancistroides, Gymnotus cf. sylvius, Phalloceros caudimaculatus, and Cichlasoma paranaense, for a total of 817 fish specimens. Phalloceros caudimaculatus (27.3\%), Pimelodella sp. (27\%), and $A$. altiparanae $(14.8 \%)$, were the most abundant species in terms of number of individuals, and A. altiparanae (54.2\%), Pimelodella sp. (20.9\%), and C. britskii (6.4\%), having the highest biomass. Crenicichla britskii was the fifth more abundant species, constituting $4.4 \%$ of the total number of collected individuals.

\subsection{Sampling methods and specimens preservation}

Sampling was done between 11:00 and 15:30 h of 6 April 2000 , utilizing electrofishing, manual seines, and hoop nets by five collectors.

Two block nets $(10 \times 2 \mathrm{~m}, 5 \mathrm{~mm}$ mesh) were set $100 \mathrm{~m}$ apart across the stream at the downstream and upstream limits of 
the stretch to be sampled. Area was then sampled in to six approximately 30 minutes long successive collecting downstream to upstream passes. Three passes were made by two collectors equipped with a conductive dip net and a spatula electrode, coupled to an alternate electric current generator $(100 \mathrm{~W}, 220 \mathrm{~V}, 3.4-4.1 \mathrm{~A})$; two passes by two collectors equipped with one manual seine $(3.5 \times 1.7 \mathrm{~m}, 5$ $\mathrm{mm}$ mesh); one pass by two collectors equipped with two metallic hoop nets $(70 \mathrm{~cm}, 2 \mathrm{~mm}$ mesh).

Fishes were fixed immediately by immersion in $10 \%$ formalin and latter transferred to ethanol $70 \%$ for permanent storage. The studied specimens were deposited in the fish collection of the Laboratorio de Ictiologia de Ribeirão Preto (LIRP), FFCLRP-Universidade de São Paulo, Brazil (LIRP 1124-25).

\subsection{Diet analysis}

Stomach contents of 20 specimens (36.1-71.3 mm SL, and 0.5-8 $\mathrm{g}$ of weight) were analyzed. The ratio of digestive tube length/standard length was calculated (DTL.SL ${ }^{-1}$ index - intestinal ratio - see Knöppel 1970), as were the frequency of occurrence (Bowen 1992) and the per cent composition (Hynes 1950) for each food item.

\section{Results}

Sixteen digestive tracts of the 20 studied specimens contained food items, in the following decreasing order of frequency: aquatic insects (Ephemeroptera, Trichoptera, Diptera, Odonata, Psocoptera, Heteroptera and Coleoptera); crustaceans (Copepoda and Ostracoda); unidentified organic material and filamentous green algae; fishes ( $P$. caudimaculatus) and arachnids (Araneae and Acari) (Table 1).

Food items grouped in broad taxonomic categories and expressed as per cent composition values show that aquatic insects $(50 \%)$ were the main components of the diet, followed by crustaceans (14.3\%), unidentified organic material and filamentous green algae (both with $10.7 \%$ ), fish and arachnids (both with 7.14\%). Looking at the ingested insects separately, we find that most were Ephemeroptera $(36 \%)$, followed by Trichoptera and Diptera (mostly Chironomidae), both with $25 \%$. The average DTL.SL ${ }^{-1}$ index was $0.71 \pm 0.15$.

\section{Discussion}

Aquatic immature insects (pupae, nymphs and larvae),

\begin{tabular}{|c|c|c|c|}
\hline Food items & FO\% & Habits and microhabitats of prey items & References \\
\hline Insecta (mostly aquatic pupae, nymphs and larvae) & 87.5 & - & - \\
\hline Ephemeroptera (Baetidae, Caenidae) (immature) & 81.25 & $\begin{array}{l}\text { Nymphs of Baetidae are swimmers and clingers, } \\
\text { while nymphs of Caenidae live on bottom and are } \\
\text { associated with submerged vegetation, being } \\
\text { important fish prey in their habitats }\end{array}$ & $\begin{array}{l}\text { Borror \& DeLong } \\
\text { 1969, Edmunds Jr. } \\
\text { \& Waltz } 1996\end{array}$ \\
\hline Trichoptera (immature) - were all found without associated cases & 56.25 & $\begin{array}{l}\text { Construct remarkable nets, refuges, and portable } \\
\text { cases, and live associated with the substrate. Most } \\
\text { larvae eat plant material and are also very important } \\
\text { prey for fish }\end{array}$ & $\begin{array}{l}\text { Wiggins 1996, } \\
\text { Borrow \& DeLong } \\
1969\end{array}$ \\
\hline Diptera (larvae) & 56.25 & - & - \\
\hline Chironomidae & 50.0 & - & - \\
\hline Orthocladiinae (Corynoneurini) & 31.25 & Live associated with macrophytes & $\begin{array}{l}\text { Trivinho-Strixino \& } \\
\text { Strixino } 1995\end{array}$ \\
\hline Tanypodinae (Pentaneurini: Ablabesmyia, Labrundinia, Larsia; Coelotanypodini) & 31.25 & Free swimming or benthic mud burrowers & Epler 1995 \\
\hline Chironominae (Chironomini, Tanytarsini) - no tube were found & 25.0 & Live in tubes or on the bottom & $\begin{array}{l}\text { Pinder \& Reiss } \\
\text { 1983, Epler 1995, } \\
\text { Trivinho-Strixino \& } \\
\text { Strixino } 1995\end{array}$ \\
\hline Ceratopogonidae & 6.25 & - & - \\
\hline Culicidae & 6.25 & $\begin{array}{l}\text { Larvae are active swimmers, feeding on algae and } \\
\text { detritus }\end{array}$ & $\begin{array}{l}\text { Walker \& Newson } \\
\text { 1996, Borror \& } \\
\text { DeLong } 1969\end{array}$ \\
\hline Odonata (larvae) & 12.5 & $\begin{array}{l}\text { Usually conceal themselves by either burrowing in } \\
\text { substrate, sitting amongst fine sediment and detritus, } \\
\text { or climbing vascular plants }\end{array}$ & $\begin{array}{l}\text { Westfall Jr. \& } \\
\text { Tennessen } 1996\end{array}$ \\
\hline Psocoptera (nymphs) & 6.25 & Live associated with vegetation & $\begin{array}{l}\text { Borror \& DeLong } \\
1969\end{array}$ \\
\hline Heteroptera (Naucoridae) (adults) & 6.25 & Surface predators & $\begin{array}{l}\text { Borror \& DeLong } \\
1969\end{array}$ \\
\hline Coleoptera (adults) & 6.25 & - & - \\
\hline Crustacea & 25.0 & - & - \\
\hline Copepoda & 25.0 & Mostly plankton forms & $\begin{array}{l}\text { Ruppert \& Barnes } \\
1996\end{array}$ \\
\hline Ostracoda & 6.25 & Live associated to the bottom & $\begin{array}{l}\text { Ruppert \& Barnes } \\
1996\end{array}$ \\
\hline Unidentified organic material & 18.75 & - & - \\
\hline Chlorophyta filamentous & 18.75 & - & - \\
\hline Teleostei (Cyprinodontiformes, Poeciliidae: Phalloceros caudimaculatus) & 12.5 & $\begin{array}{l}\text { Remain most of the time near the surface, usually } \\
\text { close to the margins }\end{array}$ & $\begin{array}{l}\text { R.M.C. Castro, pers. } \\
\text { obs. }\end{array}$ \\
\hline Arachnida & 12.5 & $\begin{array}{l}\text { Occur on the water surface or associated with the } \\
\text { vegetation }\end{array}$ & $\begin{array}{l}\text { Ruppert \& Barnes } \\
1996\end{array}$ \\
\hline Araneae & 6.25 & - & - \\
\hline Acari (Hydracarina) & 6.25 & - & - \\
\hline
\end{tabular}

Table 1. Frequency of occurrence (FO\%), habits and microhabitats of Crenicichla britskii (n=20) food items. 
were the most frequent food items, followed by crustaceans, unidentified organic material and green filamentous algae, fish and arachnids (Table 1). Green filamentous algae were probably unintentionally ingested during the capture of prey items. Almost all preys were found intact, which is in accordance with aquarium observations that $C$. britskii engulfs them quickly utilizing mouth protrusion (A.L.A. Melo \& L.S.F. Martins, pers. comm.), as do many other perciform predators (see Lauder \& Liem 1983).

Based on diet analysis, and on information on prey habits and microhabitats (Table 1), we conclude that $C$. britskii is a generalist insectivore with a relatively short digestive tube. Its diet consists of autochthonous food items captured in the water column or at the surface, buried in or over the bottom, or associated with submerged and semisubmerged macrophytes and submerged vegetation debris. Goulding et al. (1988), analyzing a relatively small number of individuals of $C$. johanna $(\mathrm{n}=1), C$. lenticulata $(\mathrm{n}=1)$ and C. lugubris ( $\mathrm{n}=9)(150-218 \mathrm{~mm} \mathrm{SL})$ from the Rio Negro, in the Brazilian Amazon, found that fish were the principal food items for those species. Alternatively, Gurgel et al. (1998) in their study of the diet of $C$. lepidota [probably $C$. menezesi, see Ploeg 1991] at Lagoa Redonda, Nisia Floresta, in the State of Rio Grande do Norte, Brazil, found that insects, crustaceans, and fish, were the major diet components of that another species of pike cichlid. Those authors also noted that qualitative and quantitative changes in diet composition were not observed with regard to sex or during the dry versus flood periods. According to Ploeg (1991), C. menezesi ranges from 42 to $146 \mathrm{~mm} \mathrm{SL}$, a size range more similar to that of the $C$. britskii specimens examined in our study (36.1-71.3 mm SL). The small prey item size is to be expected in a small size Crenicichla species such as $C$. britskii, which apparently occur only in small streams and headwaters of the Upper Rio Paraná, in which terrestrial and aquatic arthropods are the most important food items available for fishes (see Castro \& Casatti 1997, Castro 1999). The relatively short digestive tube of $C$. britskii (mean $71 \%$ of SL) is in complete agreement with its carnivore/insectivore feeding habits (see Wootton 1994).

Finally, it is noteworthy that the presence of algae and macrophytes in the digestive tract of $C$. britskii is apparently incidental to the capture of prey items in their microhabitats. Such microhabitats seem to be very important feeding places for $C$. britskii, where it exploits its most food item, immature aquatic insects that are directly and/or indirectly dependent on the riparian vegetation for subsistence. Thus, $C$. britskii, like the majority of small size stream fishes is potentially very highly sensitive to deforestation and the consequent negative modification of the riparian environmental (see Castro \& Casatti 1997, Castro \& Menezes 1998, Castro 1999).

\section{Acknowledgments}

We thank Lilian Casatti, Hertz F. Santos, and Luiz S.F. Martins for help in the field; Humberto F. Mendes for stomach content identification, suggestions and literature of prey items; Alexandre C. Ribeiro, Alex L.A. Melo, Flávio A. Bockmann, L. Casatti, Rodrigo L. Moura, and Richard P. Vari for useful suggestions on manuscript; A.L.A. Melo and L.S.F. Martins for aquarium observation data. The IBAMA gave us the collecting permit (DIREN No. 38/99). This work was partially supported by the State of São Paulo Research Foundation (FAPESP) within the BIOTA/FAPESP - The Biodiversity Virtual Institute Program (www.biota.org.br) through the Thematic Project "Diversidade de peixes de riachos e cabeceiras da bacia do Alto rio Paraná no Estado de São Paulo, Brasil/Fish diversity of the headwaters and streams of the Upper Paraná River system in State of São Paulo, Brazil" (FAPESP grant No. 98/05072-8) and by PRONEX Project "Conhecimento, Conservação e Utilização Racional da Diversidade da Fauna de Peixes do Brasil" (FINEP/CNPq grant No. 661058/1997-2). The last author is a Conselho Nacional de Desenvolvimento Científico e Tecnológico do

\section{References}

BORROR, D.J. \& DeLONG, D.M. 1969. Introdução ao Estudo dos Insetos. EDUSP, São Paulo.

BOWEN, S.H. 1992. Quantitative description of the diet. In Fisheries Techniques (L.A. Nielsen \& D.L. Johnson, eds.). American Fisheries Society, Southern Printing Company, Inc., Blacksburg, Virgínia, p.325-336.

CASTRO, R.M.C. 1999. Evolução da ictiofauna de riachos sul-americanos: padrões gerais e possíveis processos causais. In Ecologia de Peixes de Riachos (E.P. Caramaschi, R. Mazzoni \& P.R. Peres-Neto, eds.). Série Oecologia Brasiliensis, v.VI. PPGE-UFRJ, Rio de Janeiro, Brasil, p.139-155.

CASTRO, R.M.C. \& CASATTI, L. 1997. The fish fauna from a small forest stream of the Upper Paraná River basin, southeastern Brazil. Ichthyol. Explor. Freshwaters 7(4):337-352.

CASTRO, R.M.C. \& MENEZES, N.A. 1998. Estudo diagnóstico da diversidade de peixes do Estado de São Paulo. In Biodiversidade do Estado de São Paulo, Brasil: Síntese do Conhecimento ao Final do Século XX (R.M.C. Castro, ed.). Vertebrados, v.6, BIOTA-FAPESP, São Paulo, Brasil, p.1-13.

EDMUNDS JR., G.F. \& WALTZ, R.D. 1996. Ephemeroptera. In An Introdution to the Aquatic Insects of North America (R.W. Merritt \& K.W. Cummins, eds.). 3rd Edition. Kendall/Hunt Publishing Company, USA, p.126163.

EPLER, J.H. 1995. Identification Manual for the Larval Chironomidae (Diptera) of Florida. Revised Edition. Systematic Entomologist. 
FERNANDES, L.A. \& COIMBRA, A.M. 1996. A Bacia Bauru (Cretáceo Superior, Brasil). An. Acad. Bras. Ci. 68(2):195-205.

GOULDING, M., CARVALHO, M.L. \& FERREIRA, E.G. 1988. Rio Negro, Rich Life in Poor Water: Amazonian Diversity and Foodchain Ecology as Seen Through Fish Communities. SPB Academic Publishing bv, The Hague, The Netherlands.

GURGEL, H.C.B., ALMEIDA, R.C., BARBIERI, G. \& VIEIRA, L.J.S. 1998. Diet of Crenicichla lepidota Heckel, 1840 (Perciformes, Cichlidae) da lagoa Redonda, Nisia Floresta, RN. Acta-Scientiarum 20(2):191-194.

HUECK, K. \& SEIBERT, P. 1981. Vegetationskarte von Südamerika. Band IIa, Fischer, Sttutgart.

HYNES, H.B.N. 1950. The food of fresh-water sticklebacks (Gasterosteus aculeatus and Pygosteus pungitius), with a review of methods used in studies of the food of fishes. J. Anim. Ecol. 19:36-57.

KNÖPPEL, H.A. 1970. Food of Central Amazonian fishes: contribution to the nutrient-ecology of Amazonian rain forest streams. Amazoniana 2(3):257-352.

LAUDER, G.V. \& LIEM, K.F. 1983. The evolution and interrelationships of the actinopterygian fishes. Bull. Mus. Comp. Zool. 150(3):95-197.

LUCENA, C.A.S. \& KULLANDER, S.O. 1992. The Crenicichla (Teleostei: Cichlidae) species of the Uruguai River drainage in Brazil. Ichthyol. Explor. Freshwater 3(2):97-160.

NIMER, E. 1989. Climatologia do Brasil. IBGE, Rio de Janeiro, $2^{\mathrm{a}}$ ed.

PETRI, S. \& FÚLFARO, V.J. 1988. Geologia do BrasilFanerozóico. (T.A. Queiroz, ed.). EDUSP, São Paulo, v.9.

PINDER, L.C.V. \& REISS, F. 1983. The larvae of Chironominae (Diptera: Chironomidae) of the Holarctic region - keys and diagnoses. Entomol. Scandinavica, Supplement no.19, p.293-435.

PLOEG, A. 1991, Revision of the South American cichlid genus Crenicichla Heckel, 1840, with descriptions of fifteen new species and considerations on species groups, phylogeny and biogeography (Pisces, Perciformes, Cichlidae). Academisch Proefschrift, Universiteit van Amsterdam.

RUPPERT, E.E. \& BARNES, R.D. 1996. Zoologia dos Invertebrados. Ed. Roca Ltda., São Paulo, 6 a ed.
TRIVINHO-STRIXINO, S. \& STRIXINO, G. 1995, Larvas de Chironomidae (Diptera) do Estado de São Paulo: Guia de Identificação e Diagnose dos Gêneros. UFSCar, Programa de Pós-Graduação em Ecologia e Recursos Naturais (J.E. dos Santos, ed.), São Carlos, São Paulo.

WALKER, E.D. \& NEWSON, H.D. 1996. Culicidae. In An Introdution to the Aquatic Insects of North America (R.W. Merritt \& K.W. Cummins, eds.). 3rd Edition. Kendall/Hunt Publishing Company, USA, p.571-590.

WESTFALL JR., M.J. \& TENNESSEN, K.J. 1996. Odonata. In An Introdution to the Aquatic Insects of North America (R.W. Merritt \& K.W. Cummins, eds.). 3rd Edition. Kendall/Hunt Publishing Company, USA, p.164211.

WIGGINS, G.B. 1996. Trichoptera families. In An Introdution to the Aquatic Insects of North America (R.W. Merritt \& K.W. Cummins, eds.). 3rd Edition. Kendall/Hunt Publishing Company, USA, p.309-349.

WOOTTON, R.J. 1994. Ecology of Teleost Fishes. Chapman \& Hall, London.

Title: Diet of Crenicichla britskii (Perciformes:

Cichlidae) in a stream of Rio Aguapeí basin, Upper Rio Paraná system, southeastern Brazil

Authors: Fernando Zaniolo Gibran, Katiane Mara Ferreira \& Ricardo M. C. Castro

Revista Biota Neotropica, Vol. 1, numbers 1 and 2, 2001

http://www.biotaneotropica.org.br/v1n12/pt/abstract?sh ort-communication+BN01001122001

Received:August, 27, 2001

Revised: December, 12, 2001

Accepted: December 30, 2001

ISSN 1676-0611 